\title{
Occurrence of the haemocyte parasite Bonamia sp. in flat oysters Ostrea puelchana farmed in San Antonio Bay (Argentina)
}

\author{
Marina A. Kroeck ${ }^{1, *}$, Jaime Montes ${ }^{2}$ \\ ${ }^{1}$ Laboratorio de Histopatología de Moluscos, Instituto de Biología Marina y Pesquera 'Alte Storni', Güemes 1030, \\ CC: 104, San Antonio Oeste 8520 (Rio Negro), Argentina \\ ${ }^{2}$ Centro de Investigacions Mariñas, Pedras de Corón s/no ${ }^{\circ}$ Apartado 13, Vilanova de Arousa (Pontevedra) 36620, Spain
}

\begin{abstract}
Culture of native flat oysters Ostrea puelchana d'Orbigny in San Antonio Bay (San Matías Gulf, Argentina) began in 1995. After elevated mortality (33\%) occurred in September 1996, 18 mo after immersion, histopathological analysis and evaluation of parasitic prevalence was carried out. In October 1997, after 31 mo of cultivation, cumulative mortality was $80 \%$, and in December of the same year, when individuals reached marketable size, mortality was $95 \%$ and culture was discontinued. The present study describes the haemocytic parasitism that affected O. puelchana, and suggests that a Bonamia sp. was the etiological agent. This parasite should be considered as a different species from Bonamia sp. detected in Australia and New Zealand until more studies are made to determine the correct taxonomy. This work constitutes the first record of this haemocyte parasite in flat oysters from the Argentinean coast.
\end{abstract}

KEY WORDS: Bonamia sp. · Oyster culture · Ostrea puelchana · Argentina

\section{INTRODUCTION}

Bonamia ostreae is an haemocyte parasite of the European flat oyster Ostrea edulis d'Orbigny (Pichot et al. 1980). Bonamiasis has led to high mortalities in flat oysters farmed throughout Europe (Bannister \& Key 1982, Van Banning 1982, Polanco et al. 1984), and B. ostreae has been detected on the east and west coasts of the United States (Elston et al. 1986, Friedman et al. 1989). Elston et al. (1986) suggested that bonamiasis originated in the United States and that it was transferred to Europe in the late 1970s, through the importation of seed stocks. Farley et al. (1988) compared the disease caused by $B$. ostreae to the disease named 'microcell' observed in oysters from the United States in the 1960s.

Bonamiasis has also been detected in Australia, affecting Ostrea angasi (Hine 1996), and in New Zealand affecting $O$. [= Tiostrea] chilensis (Dinamani et al. 1987). According to Mialhe et al. (1988), the par- asite of $O$. chilensis should be considered as a different species from $B$. ostreae because there are structural and antigenic differences among the parasites of these 2 hosts. Hine et al. (2001a) named this parasite B. exitiosus, and Berthe \& Hine (2003) proposed B. exitiosa as the proper name of the parasite infecting $O$. chilensis in New Zealand.

Pascual et al. (1991) carried out an acclimation experiment with transplanted individuals of Ostrea puelchana (the Argentinean flat oyster) on the French coast from 1989 to 1990. High mortalities were observed, and the dead individuals were analysed. Marteilia refringens and Bonamia ostreae were identified in moribund oysters, but with low prevalence. The authors concluded that mortalities were attributable to environmental factors, and concluded that although Argentinean flat oysters were susceptible to those parasites, the infections were not believed to have caused the mortalities. 
Aquaculture in Argentina is an emerging activity, as a new way to produce bivalve molluscs. A growing private interest concerning molluscan bivalve culture has stimulated research during the past century. Experimental farming of Mytilus edulis platensis, Aequipecten tehuelchus, and Ostrea puelchana has been carried out since 1980 (Pascual \& Zampatti 1990, Zampatti 1990, Narvarte 1995, 2001).

The native flat oyster Ostrea puelchana D'Orbigny is distributed from southern Brazil to northern Patagonia, Argentina (Castellanos 1957). Dense beds have been reported only in shallow subtidal waters of the NW San Matías Gulf (41 to $42^{\circ} \mathrm{S}, 63^{\circ} 30^{\prime}$ to $65^{\circ} \mathrm{W}$ ) (Fig. 1) (Castellanos 1957). Research efforts concerning oyster culture have focused on spat collection and growout in the field (Pascual \& Bocca 1987, Pascual \& Zampatti 1990). Commercial flat oyster culture began in San Antonio Bay (Fig. 1), between March 1995 and December 1997, with the aim of exportation to the European Economic Community (EEC).

Eighteen months after the beginning of the culture, the first abnormal mortality (33\%) was recorded. After 31 months of culture, cumulative mortality was $80 \%$, and 3 months later, when individuals reached marketable size, mortality was $95 \%$. This prevented further commercial culture of Ostrea puelchana.

The preliminary diagnosis, carried out on moribund oysters, indicated the presence of a 'Bonamia-like' haemocytic parasite which was the probable etiologic agent of the mortality (Kroeck 1997).

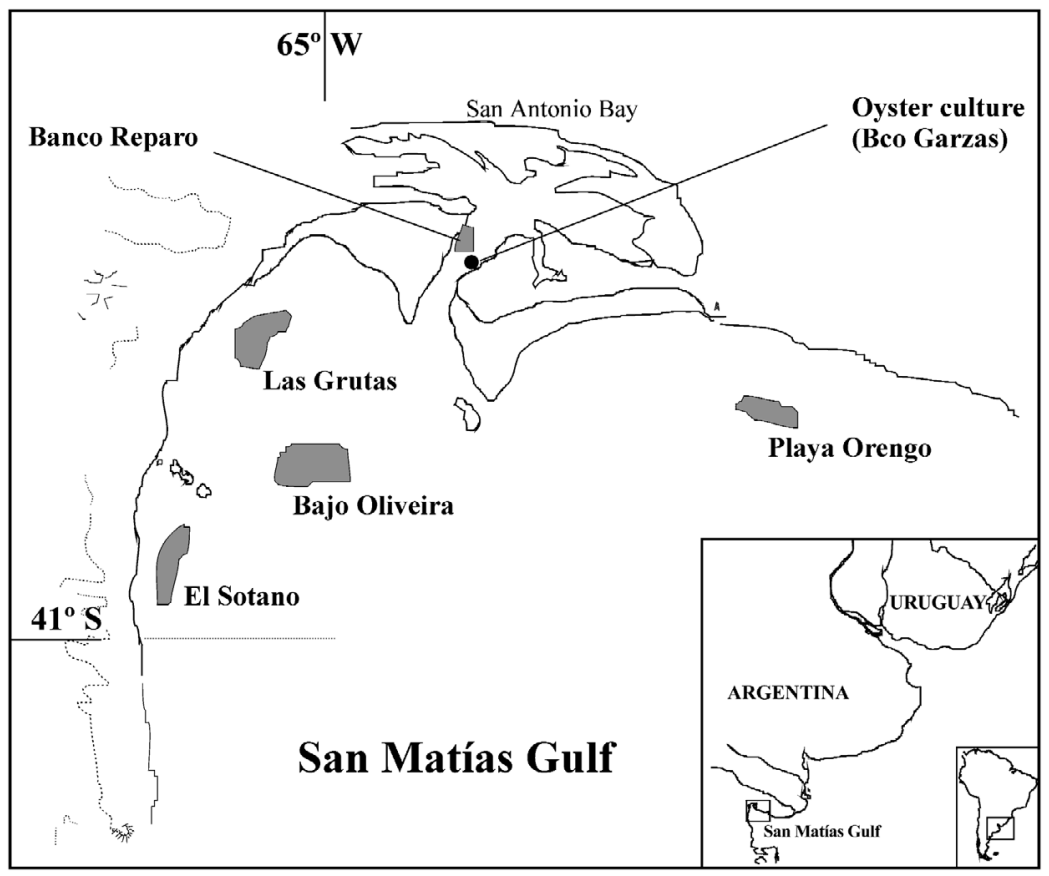

Fig. 1. San Matías Gulf, showing natural beds of Ostrea puelchana (grey shading) and the location of oyster culture (sampling station
The present study describes the haemocytic parasite that affected Ostrea puelchana. Histopathological analysis and evaluation of the parasitic prevalence were carried out during the course of commercial farming in San Antonio Bay.

\section{MATERIALS AND METHODS}

San Antonio Bay $\left(40^{\circ} 47^{\prime} \mathrm{S}\right.$ to $\left.64^{\circ} 62^{\prime} \mathrm{W}\right)$ is northwest of the San Matías Gulf (Fig 1). Oysters used for commercial culture were collected on artificial collectors placed on the oyster ground of Las Grutas during the 1994 to 1995 settlement season. In March 1995, juveniles were transferred to Banco Garzas for growout, a protected site within San Antonio Bay (Fig. 1). The oysters were placed in plastic mesh bags tied to off-bottom racks and anchored to the bottom in the intertidal zone. Samples of 30 and 60 oysters were collected in September 1996 and October 1997, respectively.

Histopathological analysis with $5 \mathrm{~mm}$ thick sagittal sections, including gill and digestive gland, was carried out. Samples were fixed with Davidson solution and embedded in paraffin wax. Sections (6 $\mu \mathrm{m}$ thick) were stained with Harris' Hematoxylin \& Eosin and examined under light microscopy for diagnosis.

\section{RESULTS}

In general, oysters showed no external symptoms of parasitic infection, although occasionally scalloping of the gill lamellae was observed in parasitised and non-parasitised individuals. In the October sample, only 10 oysters showed light emarginations or eroded gills. In these individuals, histology revealed infiltration of gill tissue by parasitised haemocytes.

A characteristic histological feature of Ostrea puelchana infected with the parasite was marked hemocytosis in some areas of connective tissue of the mantle, gills and digestive gland (Fig. 2). In September 1996, haemocytic infiltrations (HI) were present in $53 \%$ of the individuals and parasitic prevalence (PP) was 33\%. In the October 1997 sample, PP was $32 \%$ and $\mathrm{HI}$ was observed in $38 \%$ of the oysters (Table 1).

Parasitised haemocytes had an eccentric nucleus, and a variable number of parasites (1 to 8) were usually 
observed inside the cytoplasm. The parasite was basophilic, spherical or ovoid, and 2 to $3 \mu \mathrm{m}$ in diameter (Fig. 3). Some of the parasites were observed lying free in the connective tissue and ruptured haemocytes, usually with pycnotic nuclei and cells debris also observed (Fig. 4).

Bonamia sp. was most common in a few haemocytes below the basement membrane of the gut, and between the cells of the connective tissue (Leydig). These parasites were also observed in the gill, mantle, kidney and suprabranchial areas. Occurrence in the gonad was never observed.

\section{DISCUSSION}

The description of the parasite and the pathology observed in Ostrea puelchana farmed in San Antonio Bay suggest that it belongs to the pathogen group com-
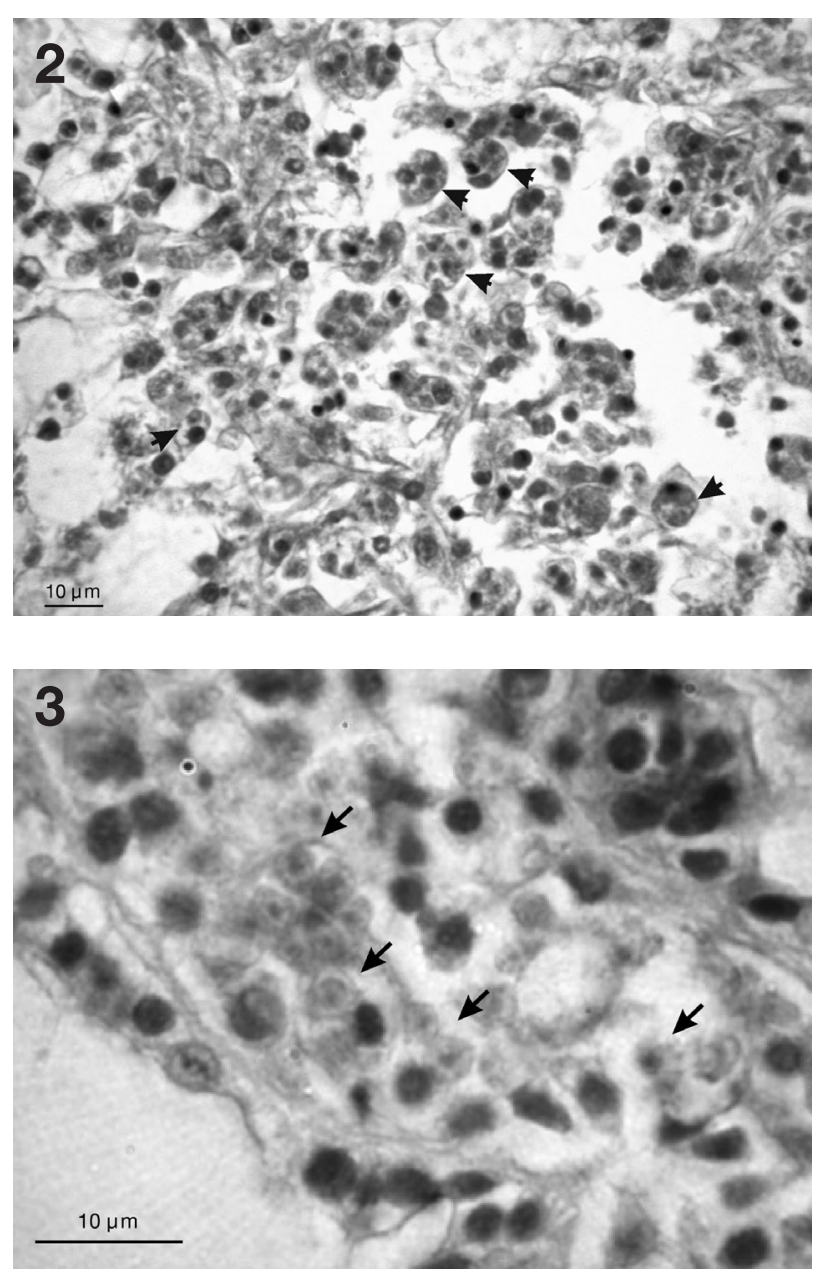

monly called 'microcells'. Microcell-type parasites of oysters, such as Bonamia ostreae (Pichot et al. 1980), B. exitiosa (= B. exitiosus) and Bonamia sp. (Dinamani et al. 1987, Hine et al. 2001a, Berthe \& Hine 2003), Mikrocytos mackini and $M$. roughleyi (Farley et al. 1988) are associated with a complex of diseases in different oyster species. These parasites are protists of a very small size that are very difficult to characterize taxonomically. Phylogenetic analysis suggests that M. roughleyi belongs in the phylum Haplosporidia, and that it should be a putative member of the genus Bonamia (Cochennec-Laureau et al. 2003), but that M. mackini is not a haplosporidian (Hine et al. 2001b) and that it may be a basal eukaryote, although it is not closely related to other known protistan taxa (Carnegie et al. 2003).

The native Argentinean flat oyster Ostrea puelchana has been referred to as a species susceptible to Bonamia ostreae and Marteilia refringens infection (Pascual et al. 1991). Hervio et al. (1994) reported that the pathogen $M$. mackini shows low host-specificity as Crassostrea gigas, $C$. virginica, O. conchaphila and $O$. edulis were all susceptible to infestation under field experiments. These alternative species (C. virginica, $O$. edulis and $O$. conchaphila) may be more susceptible to infection and the resulting disease than the usual host C. gigas (Bower et al. 1997). However, Campalans

Table 1. Ostrea puelchana. Bonamia sp. and haemocytic reactions (HR) prevalence

\begin{tabular}{|lccccc|}
\hline \multirow{2}{*}{ Month/year } & \multirow{2}{*}{$\mathrm{n}$} & \multicolumn{2}{c|}{ HR } & \multicolumn{2}{c|}{ Bonamia sp. } \\
& & $\mathrm{n}$ & $\%$ & $\mathrm{n}$ & Prev. \\
\hline $09 / 96$ & 30 & 16 & 53 & 10 & 33 \\
$10 / 97$ & 60 & 23 & 38 & 19 & 32 \\
\hline
\end{tabular}

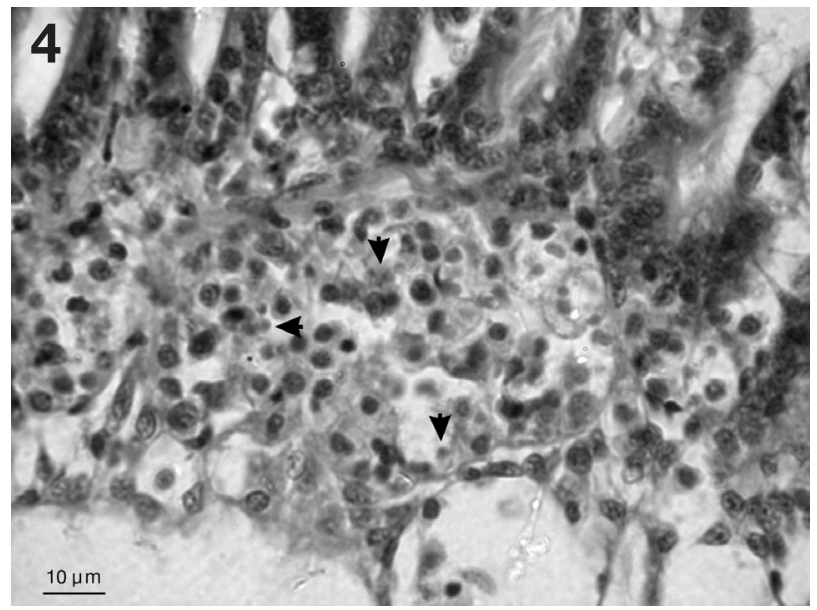

Figs. 2 to 4. Ostrea puelchana. Micrographs. Fig. 2. Infiltration of connective tissue showing Bonamia sp.-infected haemocytes (arrows) $; \times 400$. Fig. 3. Bonamia sp. (arrows) in connective tissue around digestive gland; $\times 1000$. Fig. 4. Bonamia sp. lying free (arrows) in the connective tissue; $\times 400$ 
et al. (2000) mentioned that Mikrocytos spp. affect only Crassostrea spp. oysters, therefore disregarding this species as a parasite of flat oysters Ostrea spp.

In experiments carried out in subtidal and intertidal oyster culture, Tigé \& Grizel (1984) observed that when healthy oysters Ostrea edulis were introduced to an area affected by the disease, the first stages of Bonamia ostreae were detected after 3 to $5 \mathrm{mo}$. Also, Montes (1991) found that $B$. ostreae were detected 3 to 6 mo after introducing healthy $O$. edulis in suspended culture experiments carried out in Galicia (Spain).

In exposure trials of oyster Ostrea edulis seed, Grizel (1985) reported that bonamiasis is detectable in all oyster age groups. He also found that prevalence can be greater than $30 \%$ in oysters of 24 to 30 mo. Montes (1992) stated that in culture experiences in Galicia (Spain), the first symptoms of the disease are detected in oysters $12 \mathrm{mo}$ old, and prevalence can exceed $50 \%$ in those populations reaching 18 mo of age. Cumulative mortality can exceed $80 \%$ in groups of 2 yr old oysters.

In our study, the first mortalities were detected $18 \mathrm{mo}$ after oyster-seed immersion, and the parasite was present in both September 1996 and October 1997 samples at ages of 21 and $34 \mathrm{mo}$, respectively. Cumulative mortalities were greater than $95 \%$ in oysters of 32 to 36 mo.

Although other authors have claimed that emarginated or scalloped gills are associated with parasite presence, in our case there was no such correlation. It cannot be taken for granted that the presence or absence of macroscopic gill lesions is an unequivocal criterion for diagnosis of bonamiasis. Moreover, a percentage of the haemocytic reaction may be due to stress (Hine et al. 2002), or another pathological problem not identified. Therefore, we think that since Bonamia sp. are so small, they are likely to be difficult to detect in $100 \%$ of true infections. The oysters demonstrating a haemocytic response and no detectable Bonamia sp. may in fact have a light and/or localized infection that the histological section simply missed.

In Ostrea chilensis (Hine 1991), Bonamia sp. was most common in a few haemocytes below the basement membrane of the gut and between the connective tissue cells. Furthermore, Hine (1991) reported occurrence of Bonamia sp. in the gonad, something we never observed; however, failure to detect doesn't necessarily mean absence of the parasite. B. ostreae infects the gills, including gill epithelial cells (Montes et al. 1994), but $B$. exitiosa has not been reported to infect gill epithelial cells or to cause lesions (Hine 1991). However, we observed few parasitised oysters with light emarginations or eroded gills, and parasitised haemocytes within them. We have not observed Bonamia sp. infecting gill epithelial cells.
Symptoms found in the affected oysters Ostrea puelchana, and the characteristics of the parasite, are similar to those reported for O. chilensis in Chile (Campalans et al. 2000) and in New Zealand (Dinamani et al. 1987), and for O. angasi in Australia (Hine 1996). Susceptibility of $O$. puelchana to Bonamia ostreae was also found by Pascual et al. (1991), and given these facts, it is concluded that the pathogenic parasite that affects Argentinean oysters is Bonamia sp. Moreover, Hine (1996) suggests that Bonamia sp. is an enzootic parasite of flat oysters (Ostrea spp. and Tiostrea spp.) in the southern hemisphere. Therefore, the mortalities that occurred during cultivation of the native oyster in Argentina may be due to a parasite being present in natural beds.

At the moment we propose to treat the Argentinean species as Bonamia sp., different from the European (B. ostreae), New Zealand (B. exitiosa), and Australian (Bonamia sp.) species, until more studies by electron microscopy, immunology, or molecular sequencing diagnostics are carried out to determine the correct taxonomy.

When and how the culture of Ostrea puelchana was affected by Bonamia sp. remains unclear. Some authors (Elston et al. 1986, Hine 1996) indicate that the development of the disease has taken place in several countries due to movements (introductions or transfers) of individuals from affected areas toward regions where the parasite has not been detected previously. On the other hand, the discovery of the disease could also have been due to commercial cultivation in areas where the parasite is enzootic (Hine 1996). Bonamia ostreae is thought to have occurred originally on the west coast of the USA (Friedman \& Perkins 1994), and that it moved to the east coast due to human intervention (Zabaleta \& Barber 1996, Carnegie \& Barber 2001).

At the moment, studies on samples from natural beds of the San Matías Gulf, collected in the 1970s and 1980s, are underway. These samples, together with regular sampling programs since 1996, will help us to reconstruct the origin of parasitism in natural beds of Ostrea puelchana in the San Matías Gulf. Reconstructing the history of experimental culture, starting from the 1980s in the affected area, may allow us to determine whether there has been some movement of oysters that could have introduced the pathogenic parasite into San Antonio Bay.

Acknowledgements. We are grateful to 'Ostras Patagonicas SA' for generously providing the oysters for this study, and mortality advice from Lic. E. Zampatti (Instituto de Biología Marina y Pesquera 'Alte Storni'). The work reported in this publication was financially supported by the Instituto de Biología Marina y Pesquera 'Alte Storni' and the technical support in processing the first oyster sample was provided by Centro de Investigacions Mariñas (Vilanova de Arousa, Pontevedra, Spain). Our special thanks to Dr. M. Pascual, Dr. E. Morsan and Dr. M. A. Narvarte (Instituto de Biología Marina y Pesquera 'Alte Storni') for their valuable suggestions on the manuscript. 


\section{LITERATURE CITED}

Bannister C, Key D (1982) Bonamia a new threat to the native oyster fishery. Fish Nat MAFF Direct Fish Res 71:7

Berthe FCJ, Hine PM (2003) Bonamia exitiosa Hine et al. 2001 is proposed instead of $B$. exitiosus as the valid name of Bonamia sp. infecting flat oyster Ostrea chilensis in New Zealand. Dis Aquat Org 57:181

Bower SM, Hervio D, Meyer GR (1997) Infectivity of Mikrocytos mackini, the causative agent of Denman Island disease in Pacific oysters Crassostrea gigas, to various species of oysters. Dis Aquat Org 29:111-116

Campalans M, Rojas P, Gonzalez M (2000) Haemocytic parasitosis in the farmed oyster Tiostrea chilensis. Bull Eur Assoc Fish Pathol 20(1):31-33

Carnegie RB, Barber BJ (2001) Growth and mortality of Ostrea edulis at two sites on the Damariscotta River estuary, Maine, USA. J World Aquacult Soc 32:221-227

Carnegie RB, Meyer GR, Blackbourn J, Cochennec-Laureau N, Berthe FCJ, Bower SM (2003) Molecular detection of the oyster parasite Mikrocytos mackini, and a preliminary phylogenetic analysis. Dis Aquat Org 54:219-227

Cochennec-Laureau N, Reece KS, Berthe FCJ, Hine PM (2003) Mikrocytos roughleyi taxonomic affiliation leads to the genus Bonamia (Haplosporidia). Dis Aquat Org 54:209-217

de Castellanos ZA (1957) Contribución al conocimiento de las ostras del litoral argentino (Ostrea puelchana y O. spreta). Ministerio de Agricultura y Ganaderia Nacional, Argentina

Dinamani P, Hine PM, Jones JB (1987) Occurrence and characteristics of the haemocyte parasite Bonamia sp. in the New Zealand dredge oyster Tiostrea lutaria. Dis Aquat Org 3:37-44

Elston RA, Farley CA, Kent ML (1986) Occurrence and significance of Bonamiosis in European flat oysters Ostrea edulis in North America. Dis Aquat Org 2:49-54

Farley CA, Wolf PH, Elston RA (1988) A long-term study of 'Microcell' disease in oysters with a description of a new genus, Mikrocytos (G. N.), and two new species, Mikrocytos mackini (SP. N.) and Mikrocytos roughleyi (SP. N.). Fish Bull 86(3):581-593

Friedman CS, Perkins FO (1994) Range extension of Bonamia ostreae to Maine, USA. J Invertebr Pathol 64:179-181

Friedman CS, Mc Dowell T, Gorff JM, Hollibugh JT, Manzer D, Hedrick RP (1989) Presence of Bonamia ostreae among populations of the European flat oyster Ostrea edulis Linnée, in California, USA. J Sellfish Res 8(1):133-137

Grizel H (1985) Etudes des recentes epizooties de l'huître plate Ostrea edulis (Linne) et de leur impact sur l'ostreiculture bretonne. PhD thesis, Université des Sciences Techniques du Languedoc, Montpellier

Hervio D, Bower S, Meyer GR (1994) Life cycle, distribution and lack of host specificity of Mikrocytos mackini, the cause of Denman Island Disease in Pacific Oysters Crassostrea gigas. Abstracts, National Shellfisheries Association meeting, October 2-4, Seaside, OR, p 228

Hine PM (1991) The annual pattern of infection by Bonamia sp. in New Zealand flat oysters, Tiostrea chilensis. Aquaculture 93:241-251

Hine PM (1996) The ecology of Bonamia and decline of Bivalve Molluscs. NZ J Ecol 20(1):109-116

Hine PM, Cochenec-Laureau N, Berthe FCJ (2001a) Bonamia exitiosus n. sp. (Haplosporidia) infecting flat oysters Ostrea chilensis in New Zealand. Dis Aquat Org 47:63-72

Hine PM, Bower SM, Meyer GR, Cochennec-Laureau N, Berthe FCJ (2001b) Ultrastructure of Mikrocytos mackini, the cause of Denman Island disease in oysters Crassostrea spp. and Ostrea spp. in British Columbia, Canada. Dis Aquat Org 45:215-227

Hine PM, Diggles BK, Parsons MJD, Prigle A, Bull B (2002) The effects on the dynamics of Bonamia exitiosus Hine, Cochennec-Laureau \& Berthe, infections in flat oysters Ostrea chilensis (Philippi). J Fish Dis 25:545-554

Kroeck MA (1997) Análisis histopatológicos de ejemplares adultos de la ostra plana autóctona, Ostrea puelchana, procedentes de cultivos y bancos naturales del Golfo San Matías. Informe Técnico $\mathrm{N}^{\circ}$ 5. Instituto de Biologìa Marina y Pesquera 'Alte Storni'

Mialhe E, Boulo V, Elston R, Hill B, Hine PM, Montes J, Van Banning P, Grizel H (1988) Serological anaysis of Bonamia in Ostrea edulis and Tiostrea lutaria using polyclonal and monoclonal antibodies. Aquat Living Resour 1:67-69

Montes J (1991) Lag time for the infestation of flat oyster (Ostrea edulis L.) by Bonamia ostreae in estuaries of Galicia (N. W. Spain). Aquaculture 93:235-239

Montes J (1992) Estudio de la Bonamiosis de la ostra plana (Ostrea edulis L.) en galicia: epidemiología y ciclo celular. $\mathrm{PhD}$ thesis, Universidad de Santiago de Compostela

Montes J, Anadon R, Azevedo C (1994) A possible cycle for Bonamia ostreae on the basis of electron microscopy. J Invertebr Pathol 63:1-6

Narvarte MA (1995) Spat collection and growth to commercial size of the tehuelche scallop Aequipecten tehuelchus (D'Orb.) in the San Matías Gulf, Argentina. J World Aqucult Soc 26(1):59-64

Narvarte MA (2001) Settlement of tehuelche scallop, Aequipecten tehuelchus D'Orb., larvae on artificial substrata in San Matías Gulf (Patagonia, Argentina). Aquaculture 196:55-65

Pascual MS, Bocca AH (1987) Cultivo experimental de la ostra puelche, Ostrea puelchana D'Orb., en el Golfo San Matías, Argentina. In: Verreth J, Carrillo M, Zanuy S, Huisman EA (eds) Aquaculture research in Latin America. Pudoc, Wageningen, p 329-345

Pascual M, Zampatti E (1990) Cultivo de la ostra plana (Ostrea puelchana), en Argentina. In: Armando Hernández R (ed) Cultivo de Moluscos en América Latina. Memorias segunda reunión grupo de trabajo têcnico, Ancud (Isla de Chiloe, Chile), Noviembre 7-11, 1989. Centro Internacional de Investigaciones para el Desarrollo/Canada, Bogota, Columbia, p 129-136

Pascual M, Martin A, Zampatti E, Coatanea D, Defossez J, Robert R (1991) Testing of the Argentina oyster, Ostrea puelchana, in several French oyster farming sites. Cons Int Expl Mer, CM 1991/K 30

Pichot Y, Comps M, Tigé G, Grizel H, Rabouin MA (1980) Recherches sur Bonamia ostreae Gen. N., sp. N., parasite nouveau de l'huitre plate Ostrea edulis L. Rev Trav Inst Pêch Marit 43(1):131-140

Polanco E, Montes J, Outon M J, Melendez MI (1984) Situation pathologique de stock d'huitres plates en Galice (Espagne) en relation avec Bonamia ostreae. Haliotis 14:91-95

Tigé G, Grizel H (1984) Essai de contamination d'Ostrea edulis Linne par Bonamia ostreae (Pichot et al. 1980) en riviére de Crach (Morbihan). Rev Trav Inst Pêch Marit 46(4):307-314

Van Banning P (1982) Some aspects of the occurrence, importance and control of the oyster pathogen Bonamia ostreae in the Dutch oyster culture. In: Burges HD, Payne CC (eds) Invertebrate pathology and microbial control. Proceedings of the 15th Annual Meeting of the Society of Invertebrate Pathologists, 6-10 September, Brighton, p 261-265

Zabaleta A, Barber BJ (1996) Prevalence, intensity, and detection of Bonamia ostreae in Ostrea edulis in Damariscotta River, Maine. J Shellfish Res 15:395-400

Zampatti E (1990) El Cultivo del mejillón (Mytilus edulis platensis) y de la vieira (Chlamys tehuelcha), en Argentina. In: Armando Hernández . (ed) Cultivo de Moluscos en América Latina. CIID, Canada, p 119-128 